Human and Animal Health

\title{
Chromosome Mapping and Molecular Characterization of the Tc1/Mariner Element in Rineloricaria (Siluriformes: Loricariidae)
}

\author{
Cleberson Cezario Primo ${ }^{1}$, Larissa Glugoski ${ }^{1}$, Marcelo Ricardo Vicari ${ }^{1}$, Viviane Nogaroto ${ }^{1 *}$
}

${ }^{1}$ Universidade Estadual de Ponta Grossa - Biologia Estrutural, Molecular e Genética, Ponta Grossa, Paraná, Brasil

\begin{abstract}
The Tc1/Mariner sequence was isolated and mapped on chromosomes aiming to verify the association of this transposable element (TE) and chromosomal rearrangements in Rineloricaria. Cytogenetic analysis showed that Tc1/Mariner does not co-localize with chromosomal fusion points, in addition the analysis revealed intense molecular degeneration in its DNA sequence.
\end{abstract}

Key words: chromosome rearrangement; double-FISH; transposon.

\footnotetext{
*Author for correspondence: vivianenogaroto@hotmail.com
} 
Among repetitive sequence classes, transposable elements (TEs) have been studied for their importance in the modulation of biological events, especially evolutionary processes. They are considered hotspots of mutation, and cytogenetic and molecular analyses have demonstrated the role of TEs in chromosomal rearrangements. TEs can be divided into two categories according to their structural organization and transposition mechanism: class I (retrotransposons - RTEs), which use an intermediate RNA; and class II (DNA transposons), which insert directly into the genome ${ }^{1}$. Among the existing transposon subclasses, the superfamily Tcl/Mariner stands out for having the widest distribution in nature. These elements consist of approximately $1000-$ $5000 \mathrm{bp}$ and are characterized by containing an open reading frame (ORF) which encodes a transposase flanked by two terminal inverted regions (TIRs) that are flanked by TA nucleotides 2 .

In Gymnotiformes, da Silva et al. ${ }^{3}$ located in situ multiple clusters of 5S rDNA, which was attributed to the Tc1/Mariner element present in the non-transcribed spacer sequence (NTS) of the 5S rDNA, contributing to the dispersion of this rDNA in the analyzed species. In Parodontidae, Schemberger et al. ${ }^{4}$ found non-autonomous copies of Tc1/Mariner with structural variations and different levels of degeneration. Physical mapping of this TE on Parodontidae chromosomes revealed dispersed signals in euchromatins, and some accumulations in terminal regions and sex chromosomes 4 .

Loricariidae is the largest family of the Siluriformes order and is subdivided into seven subfamilies ${ }^{5}$. The genus Rineloricaria Bleeker, 1862 contains the greatest number of species in the Loricariinae family ${ }^{6}$ and shows extensive karyotype variation $(2 n=36-70)$, which is attributed to Robertsonian ( $\mathrm{Rb})$ events associated with gametic combinations and inversion mechanisms ${ }^{7-10}$.

Recently, Glugoski et al. ${ }^{11}$ reported the probable involvement of TE $h A T$ in the dispersion of 5S rDNA sites in the Rineloricaria latirostris genome, which could explain part of the chromosome rearrangements presented in this group. Considering the extensive karyotype variation of Loricariidae, the presence of multiple 5S rDNA sites in some species of Rineloricaria ${ }^{10}$ and the lack of studies that correlate the involvement of TEs with chromosomal rearrangements, the mapping and molecular analysis of Tcl/Mariner could contribute to the understanding of chromosome diversification in this group. The Tc1/Mariner element was therefore isolated, characterized and mapped on chromosomes in order to analyze chromosomal diversification in the Rineloricaria species.

In this study, fifty-eight specimens of different populations of Rineloricaria were genetically analyzed: R. latirostris (Laranjinha river - Ventania/PR, Brazil); R. pentamaculata (Juruba river - Apucarana/PR, Brazil); R. stellata and R. capitonia (Uruguai river - São Carlos/SC, Brazil). The procedures were performed according to the Instituto Chico Mendes de Conservação da Biodiversidade (ICMBio/SISBIO: 15117-1). The research was approved by the Ethics Committee of Animal Usage (Process CEUA 028/2016) of the Universidade Estadual de Ponta Grossa.

Genomic DNA was extracted from liver using the cetyltrimethylammonium bromide (CTAB) method ${ }^{12}$. The Tc1/Mariner element was amplified by polymerase chain reaction (PCR), using a single primer for the TIRs ${ }^{4}$. Approximately 1200-bp-long DNA fragments were isolated, cloned into Escherichia coli DH5 $\alpha$ and sequenced. The clones obtained were labeled as probes for the physical mapping of Tc1/Mariner on chromosomes, according to Pinkel et al. ${ }^{13}$.

Mitotic chromosomes were obtained according to Blanco et al. ${ }^{14}$. For fluorescence in situ hybridization (FISH), the following probes were used: i) $5 \mathrm{~S} \mathrm{rDNA}^{15}$ labeled with digoxigenin 11-dUTP (Roche Applied Science) and amplified by PCR; and, ii) Tc1/Mariner labeled using the Biotin-Nick Translation Mix (Roche Applied Science). Signal detection was performed using antibodies Streptavidin Alexa Fluor 488 (Molecular Probes) and anti-digoxigenin rhodamine (Roche Applied Science). Chromosomes were counterstained with 4',6-diamidino-2phenylindole (DAPI $0.2 \mu \mathrm{g} / \mathrm{mL}$ ) in mounting medium Vectashield (Vector).

Cytogenetic data showed $2 \mathrm{n}=46$ chromosomes for $R$. latirostris; $2 \mathrm{n}=56$ chromosomes for $R$. pentamaculata; $2 \mathrm{n}=54$ chromosomes for $R$. stellata; and, $2 \mathrm{n}=64$ chromosomes for $R$. capitonia ${ }^{10}$. As previously described by Primo et al. ${ }^{10}$, hybridization with $5 \mathrm{~S}$ rDNA probes presented the following chromosomal markers: $R$. latirostris - six pairs marked ( $\mathrm{m}$ chromosome pair 3 in the centromeric region and five st/a pairs in the terminal region); $R$. pentamaculata - five acrocentric pairs marked in the terminal region; $R$. stellata - five chromosome pairs; $R$. capitonia - four st/a pairs with markers in terminal sites. FISH mapping of the Tcl/Mariner sequence revealed 
dispersed markers over the chromosomes of all analyzed species, with no accumulations (Fig. 1a, b, c, d). In addition, Tc1/Mariner sites did not co-locate with the 5S rDNA sites.

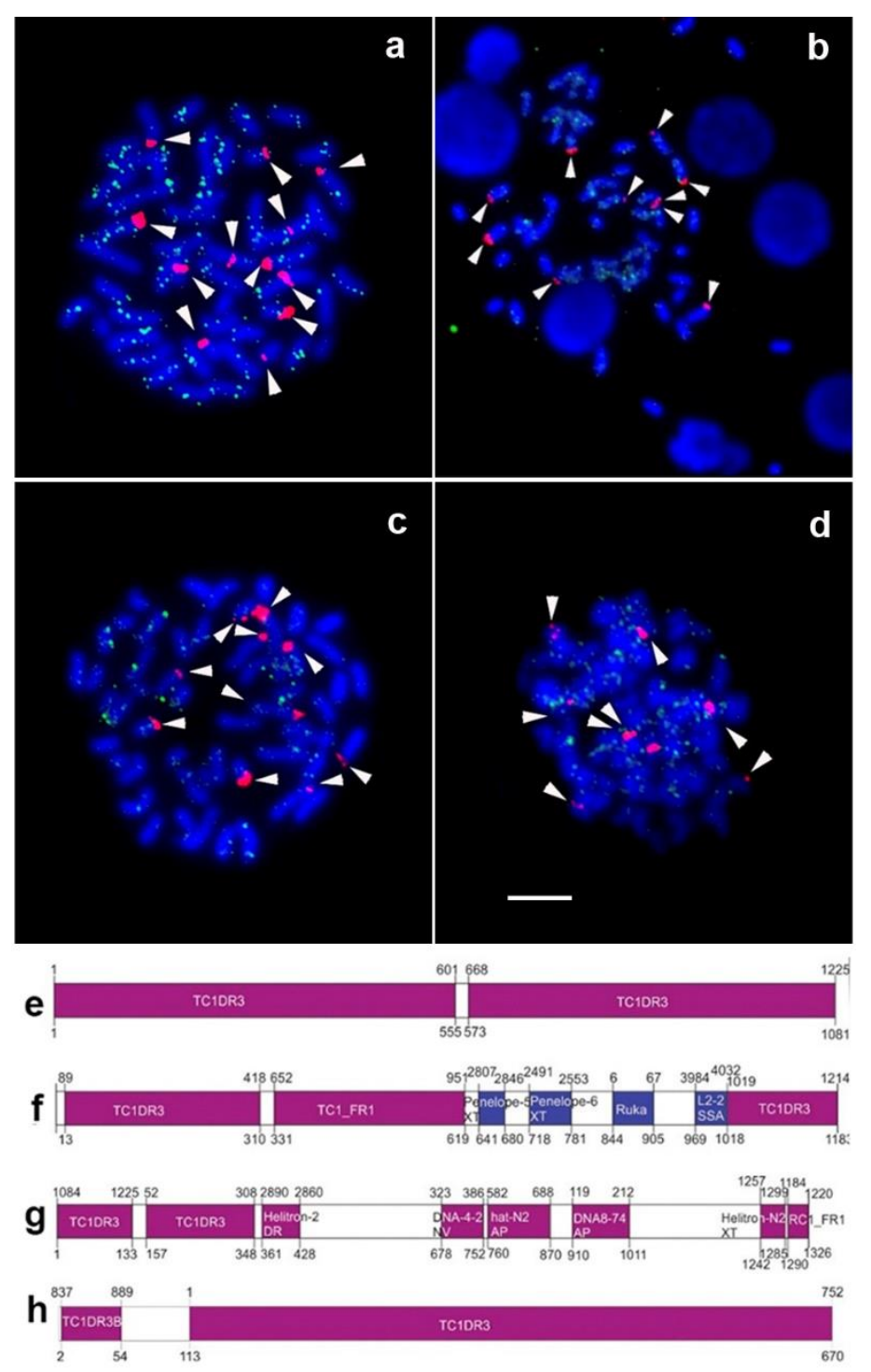

Figure 1. Karyotypes of Rineloricaria individuals submitted to FISH using 5S rDNA (arrows, in red) and R. latirostris Tcl/Mariner (in green) probes. (a) R. latirostris; (b) R. pentamaculata; (c) R. stellata; and, (d) R. capitonia. Schematic figures of Tcl/Mariner sequences are shown in (e) R. latirostris, (f) R. pentamaculata, (g) R. stellata and (h) $R$. capitonia. Bar $=10 \mu \mathrm{m}$. 
Table 1. Characterization of the Tc1/Mariner nucleotide sequences obtained from species of Rineloricaria, according to CENSOR software.

\begin{tabular}{|c|c|c|c|c|c|}
\hline Rineloricaria individuals & TE description & $\begin{array}{c}\text { TE nucleotide } \\
\text { sequence } \\
\text { position }\end{array}$ & $\begin{array}{l}\text { Nucleotide position of } \\
\text { the reference TE } \\
\text { (CENSOR) }\end{array}$ & Categories & $\begin{array}{l}\text { Degree of DNA } \\
\text { similarity }\end{array}$ \\
\hline \multirow[t]{2}{*}{ R. latirostris } & $T C 1 D R 3$ & $1-555$ & $1-601$ & DNA & 0.8217 \\
\hline & $T C 1 D R 3$ & $573-1081$ & $668-1225$ & DNA & 0.8031 \\
\hline \multirow[t]{7}{*}{ R. pentamaculata } & TC1DR3 & $13-310$ & $89-418$ & DNA & 0.7855 \\
\hline & TCl FRl & $331-619$ & $652-951$ & DNA/Mariner & 0.7840 \\
\hline & Penelope-5 XT & $641-680$ & $2807-2846$ & NonLTR/Penelope & 0.8780 \\
\hline & Penelope-6 XT & $718-781$ & $2491-2553$ & NonLTR/Penelope & 0.8000 \\
\hline & Ruka & $844-905$ & $6-67$ & NonLTR/SINE/SINE2 & 0.7258 \\
\hline & $L 2-2 S S a$ & $969-1017$ & $3984-4032$ & NonLTR/L2 & 0.8776 \\
\hline & TC1DR3 & $1018-1183$ & 1019-1214 & DNA & 0.8070 \\
\hline \multirow[t]{8}{*}{ R. stellata } & $T C 1 D R 3$ & $1-133$ & $1084-1225$ & DNA & 0.8074 \\
\hline & $T C 1 D R 3$ & $157-348$ & $52-308$ & DNA & 0.8477 \\
\hline & Helitron-2 DR & $361-428$ & $2890-2960$ & DNA/Helitron & 0.7183 \\
\hline & $D N A-4-2 N V$ & $678-752$ & $323-386$ & DNA & 0.7794 \\
\hline & hat-N2 AP & $760-870$ & $582-688$ & DNA/hat & 0.7570 \\
\hline & DNA8-74 AP & $910-1011$ & $119-212$ & DNA & 0.7753 \\
\hline & Helitron-N2 XT & $1242-1285$ & $1257-1299$ & DNA/Helitron & 0.8409 \\
\hline & RCl FRI & $1290-1326$ & $1184-1220$ & DNA/Mariner & 0.8378 \\
\hline \multirow[t]{2}{*}{ R. capitonia } & $T C 1 D R 3 B$ & $2-54$ & $837-889$ & DNA/Mariner & 0.8679 \\
\hline & $T C 1 D R 3$ & $113-670$ & $1-752$ & DNA & 0.8462 \\
\hline
\end{tabular}


A high degree of deterioration in the Tc1/Mariner nucleotide sequences was observed, with truncated regions and absence of intact ORFs (Table 1; Fig. 1e, f, g, h). The analysis of similarity performed using CENSOR online software ${ }^{16}$ revealed that the 1081-bp Tc1/Mariner sequence from $R$. latirostris (GenBank accession no. MF598590) presented similarities to Danio rerio Tc1/Mariner (TC1DR3) (Table 1; Fig. 1e). In R. pentamaculata, the 1183-bp amplified sequence (GenBank accession no. MF598591) showed similarities to TC1DR3, Takifugu rubripes Tc1/Mariner (TC1-FR1), long interspaced nuclear elements (LINEs) Penelope-5_XT and Penelope-6_XT from Xenopus tropicalis, short interspersed nuclear element (SINE) Ruka from Ixodida and LINE L2-2_SSa from Salmo salar (Table 1; Fig. 1f). In R. stellata, the 1326-bp amplified sequence (GenBank accession no. MF598592) showed similarities to regions of TC1DR3, Helitron-2 DR from D. rerio, DNA-4-2 NV from Nematostella vectensis, hat-N2 AP and DNA8-74 AP from Acyrthosiphon pisum, Helitron-N2 XT from Xenopus tropicalis and Mariner RC1 FRl from Takifugu rubripes (Table 1; Fig. 1g). The 670-bp TE DNA sequence from $R$. capitonia (GenBank accession no. MF598593) showed similarities to TC1DR3 and TC1DR3B transposon segments from D. rerio, without identification of any ORF (Table 1; Fig. $1 \mathrm{~h})$.

Repetitive DNA sequences are hotspots for chromosomal breaks and rearrangements in eukaryotes ${ }^{17}$ and it is known that fish from the Loricariinae subfamily show a wide karyotype diversity ${ }^{7,9,10}$. Symonová et al. ${ }^{18}$ proposed that in some cases, rDNAs use the spread mechanism of TEs to increase the number of its copies and, as a consequence, they affect recombination rates, leading to karyotype differentiation among close genomes. Studies indicate a relation between 5S rDNA dispersion throughout genomes and TEs in fish ${ }^{19}$. RTE fragments of LINE CR1-79_HM and the long terminal repeat (LTR) Gypsy were found in Diplodus sargus 5S rDNA NTS ${ }^{20}$. Da Silva et al. ${ }^{3}$ sequenced 5S rDNA from the Gymnotiformes species and found fragments of the Tc1/Mariner in the NTS. The dispersion of 5S rDNA in at least 19 chromosome pairs from Gymnotus paraguensis was attributed to this $\mathrm{TE}^{3}$. Glugoski et al. ${ }^{11}$ indicated a possible association between the TE $h A T$ and the dispersion of $5 \mathrm{~S}$ rDNA sites in a population of $R$. latirostris, which could contribute to the karyotypic diversification present in Loricariidae.

The Rineloricaria species evaluated in this study presented several chromosome pairs bearing $5 \mathrm{~S}$ rDNA sites, some of which were located in the centromeric region of metacentric chromosomes as a result of centric fusion ${ }^{10}$. Double FISH data, using $5 \mathrm{~S}$ rDNA and Tc1/Mariner probes, revealed no association between these sequences, moreover, the TE nucleotide sequence did not show any similarity to the 5S rDNA sequence. Therefore, the dispersion of 5S rDNA sites and the mechanisms related to chromosomal fusions/fissions, common in this fish group, could not be correlated to the Tc1/Mariner element. It is probable that other TEs, such as the $h A T$ element ${ }^{11}$, may be involved in the dispersion of $5 \mathrm{~S}$ rDNA and chromosomal fusions in Rineloricaria.

Sequencing data of Tc1/Mariner isolated from four Rineloricaria species revealed the absence of active ORFs in all analyzed clones and high levels of Tc1/Mariner molecular deterioration, which could influence its activity as a TE ${ }^{21}$. Clones obtained from $R$. pentamaculata and $R$. stellata contained insertions of several other TEs, characterized as composite transposons, between the TIRs. Among eukaryotes, TEs are usually present as non-autonomous copies generated through a degradation process ${ }^{21}$; when TEs become inactivated, they accumulate mutations, thereby losing their identity. Nucleotide sequences of $T c 1$ families are usually inactivated, including those in fish genomes ${ }^{4,22}$. Some mutated TEs can undergo the evolutionary process of "molecular domestication", losing their TE features and acquiring new functions ${ }^{23}$, including genetic regulation at both the transcriptional and post-transcriptional levels, the generation of transcription factor binding sites, and RNA editing and translation processes ${ }^{24,25}$. Thus, due to the intense molecular degeneration of Tcl/Mariner elements isolated from Rineloricaria, it is probable that they act in other functions or remain as inert material in the genome. The Tc1/Mariner results also revealed degenerated sequences in the Parodontidae species. However, transcriptional activity of these degenerated sequences was detected in the gonads of this species, which may indicate the synthesis of functionless truncated proteins or the synthesis of new proteins with novel functions, since the presence of ORFs corresponding to proteins with ligation domains derived from Tc1/Mariner of Parodontidae were detected ${ }^{4}$.

The combination of transposons and RTEs found in Tc1/Mariner from Rineloricaria may have been the result of unequal crossover between close TEs, or may indicate the insertion of one TE into another ${ }^{26}$. The sequences obtained in the present study could be correlated to miniature 
inverted repeat transposable elements (MITEs), since they contain terminal ends with greater identity to Mariner and the absence, or intense degeneration, of the transposase domain ${ }^{21}$. Eukaryotic genomes rarely have complete autonomous TEs sequences, with degenerate nonautonomous TEs being more frequent ${ }^{22}$.

In conclusion, the data obtained in this study show no association between the Tc1/Mariner element, the dispersion of 5S rDNA sites and Rb events in Rineloricaria. The sequences obtained could be characterized as being Tc1/Mariner-like, highly degenerate and with no TE function. However, these degenerate sequences could be related to other genomic functions in the species studied here.

\section{ACKNOWLEDGEMENTS}

The authors are grateful to Instituto Brasileiro do Meio Ambiente (IBAMA/MMA/SISBIO n: 15117), CNPq (Conselho Nacional de Desenvolvimento Científico e Tecnológico), CAPES (Coordenação de Aperfeiçoamento de Pessoal de Nível Superior), SETI/UGF (Secretaria de Estado da Ciência, Tecnologia e Ensino Superior/Unidade Gestora do Fundo do Paraná) and Fundação Araucária (Fundação Araucária de Apoio ao Desenvolvimento Científico e Tecnológico do Estado do Paraná) and FAPESP (Fundação de Amparo à Pesquisa do Estado de São Paulo) funding.

\section{REFERENCES}

1. Wicker T, Sabot F, Hua-Van A, Bennetzen JL, Capy, P, Chalhoub B, et al. A unified classification system for eukaryotic transposable elements. Nat Rev Genet. 2007; 8(12): 973 982.

2. Plasterk RHA, Izsvák Z, Ivics Z. Resident aliens: the Tcl/mariner superfamily of transposable elements. Trends Genet. 1999; 15(8): 326-332.

3. Da Silva M, Matoso DA, Vicari MR, Almeida MC, Margarido VP, Artoni RF. Physical mapping of $5 \mathrm{~S}$ in two Species of Knifefishes: Gymnotus pantanal and Gymnotus paraguensis (Gymnotiformes). Cytogenet Genome Res. 2011; 134: 303-307.

4. Schemberger MO, Nogaroto V, Almeida MC, Artoni RF, Valente GT, Martins C, et al. Sequence analyses and chromosomal distribution of the Tc1/Mariner element in Parodontidae fish (Teleostei: Characiformes). Gene. 2016; 593(2): 308-314.

5. Lujan NK, Armbruster JW, Lovejoy NR, López-Fernández H. Multilocus molecular phylogeny of the suckermouth armored catfishes (Siluriformes: Loricariidae) with a focus on subfamily Hypostominae. Mol Phylogenet Evol. 2015; 82: 269-288.

6. Froese R, Pauly D. (Eds.), 2017. FishBase. World Wide Web Electronic Publication. www.fishbase.org (version 2017).

7. Errero-Porto F, Vieira MM, Barbosa LM, Borin-Carvalho LA, Vicari MR, Portela-Castro $\mathrm{AL}$, et al. Chromosomal polymorphism in Rineloricaria Lanceolata Günther, 1868 (Loricariidae: Loricariinae) of the Paraguay Basin (Mato Grosso do Sul, Brazil): Evidence of fusions and their consequences in the population. Zebrafish. 2014; 11(4): 318-324.

8. Giuliano-Caetano L (1998). Polimorfismo cromossômico Robertsoniano em populações de Rineloricaria latirostris (Pisces, Loricariidae). Tese, Universidade Federal de São Carlos, São Carlos, Brazil.

9. Rosa KO, Ziemniczak K, Barros AV, Nogaroto V, Almeida MC, Cestari MM, et al. Numeric and structural chromosome polymorphism in Rineloricaria lima (Siluriformes: Loricariidae): fusion points carrying $5 \mathrm{~S}$ rDNA or telomere sequence vestiges. Rev Fish Biol Fish. 2012; 22: 739-749.

10. Primo CC, Glugoski L, Almeida MC, Zawadzki HC, Moreira-Filho O, Vicari MR, et al. Mechanisms of chromosomal diversification in species of Rineloricaria (Actinopterygii: Siluriformes: Loricariidae). Zebrafish. 2017; 14(2): 161-168.

11. Glugoski L, Giuliano-Caetano L, Moreira-Filho O, Vicari MR, Nogaroto V. Co-located $h A T$ transposable element and 5S rDNA in an interstitial telomeric sequence suggest the formation of Robertsonian fusion in armored catfish. Gene. 2018; 650: 49-54.

12. Murray GM, Thompson WF. Rapid isolation of high molecular weight plant DNA. Nucleic Acids Res. 1980; 8(19): 4321-4325. 
13. Pinkel D, Straume T, Gray JW. Cytogenetic analysis using quantitative, high-sensitivity, fluorescence hybridization. Proc Natl Acad Sci. 1986; 83(9): 2934-2938.

14. Blanco DR, Bertollo LAC, Vicari MR, Margarido VP, Artoni RF, Moreira-Filho O. A new technique for obtaining mitotic chromosome spreads from fishes in the field. J Fish Biol. 2012; 81(1): 351-357.

15. Martins C, Galetti Jr PM. Chromosomal localization of 5S rDNA genes in Leporinus fish (Anostomidae, Characiformes). Chromosome Res. 1999; 7(5): 363-367.

16. Jurka J, Kapitonov VV, Pavlicek A, Klonowski P, Kohany O, Walichiewicz J. Repbase Update, a database of eukaryotic repetitive elements. Cytogenet Genome Res. 2005; 110: 462-467.

17. Kidwell MG. Transposable elements and the evolution of genome size in eukaryotes. Genetica. 2002; 115(1): 49-63.

18. Symonová R, Majtánová S, Sember A, Staaks GBO, Bohlen J, Freyhof J, et al. Genome differentiation in a species pair of coregonine fishes: an extremely rapid speciation driven by stress-activated retrotransposons mediating extensive ribosomal DNA multiplications. BMC Evol Biol. 2013; 13: 1-11.

19. Rebordinos L, Cross I, Merlo A. High evolutionary dynamism in 5S rDNA of Fish: State of the Art. Cytogenet Genome Res. 2013; 141(2-3): 1-11.

20. Merlo MA, Cross I, Manchado M, Cárdenas S, Rebordino L. The 5S rDNA high dynamism in Diplodus sargus is a Transposon-Mediated Mechanism. Comparison with other multigene families and sparidae species. J Mol Evol. 2013; 76(3): 83-97.

21. Fernández-Medina RD, Ribeiro JMC, Carareto CMA, Velasque L, Struchiner CJ. Losing identity: structural diversity of transposable elements belonging to different classes in the genome of Anopheles gambiae. BMC Genomics. 2012; 13: 272.

22. Muñoz-López M, García-Pérez JL. DNA transposons: nature and applications in genomics. Curr Genomics. 2010; 11(2): 115-128.

23. Sinzelle L, Izsvák Z, Ivics Z. Molecular domestication of transposable elements: from detrimental parasites to useful host genes. Cell Mol Life Sci. 2009; 66(6): 1073-1093.

24. Feschotte C, Pritham EJ. DNA Transposons and the Evolution of Eukaryotic Genomes. Annu Rev Genet. 2007; 41: 331-368.

25. Herpin A, Braasch I, Kraeussling M, Schmidt C, Thoma EC, Nakamura S, et al. Transcriptional rewiring of the sex determining dmrt1 gene duplicate by transposable elements. PLoS Genet. 2010; 6(2): e1000844.

26. Schemberger MO, Oliveira JIN, Nogaroto V, Almeida MC, Artoni RF, Cestari, MM, et al. Construction and characterization of a repetitive DNA library in Parodontidae (Actinopterygii: Characiformes): a genomic and evolutionary approach to the degeneration of the W sex chromosome. Zebrafish. 2014; 11(6): 518-527.

Received: September 26, 2017

Accepted: April 25, 2018 